\title{
MITNING ACT IVITIES
}

FIRST DIVISION - OUr assay office at Ketchikan is again open for business at the seme old locstion until further notice. Although the city-owred lot and building were to be sold as reported in the June Bulletin, no sale has yet been effected, acd lategt information indicates that the deal may not be closed for some time. so for an indefinte period, we are agaln open for assistance to the prospecting and mising public at the old stand.

An eirborne magnetometer survey was made during the past month of the Admiralty-Aleska nickel-copper deposit and vicinity near Funter Bay. The conpany making the survey was Conadian Aero Service, Itd. of Canada, A special permit had to be obtalned from the Civ1l Aeronautics Boerd to allow then to use their Canadian two-motor Anson plane for tho work. The mineralization at the Funter Bey property is highly magnetic, and the resulting eero magnetic map of the property and vicinity will do much toward the proper directing of future developient of the property. The same crew also made an eerial ourvey of the Port Snettisham megnet1te deposit, which 19 partly held by $W$. $s$. Pekovich, one of the Admiralty-Alaska prinefpals.

SECOND DIVISION - Shortage of funds in the TDM's approprtation 1s delaying the completion of the new assay offlce and laboratory at Nome. It was hoped to bavo this office in operation by late summer, but it appears now that this will probably not be the case. The starting date when samples may be sent to this office for assay will be announoed as soon as possible. In the meantime, technical halp and information can be obtained there fron Pete Sandvik, Englneer-Assajer.

A surprialng amount of Interest has been shown lately in the old Independence aliver-lead mine, a one-time producer at the confluence of Independence Creek and the Yugruk RIter on the Seward Feninsula. The most recent indication is a formal requ st to the TDM for an englneer's examination of the property from Archie Ferguwon of Kotzebue. Mr. Ferguson ztates he has plans for putting the mine back into operation.

THIRD DIVISION - W. A. Richerdson, Toronto mining promoter, has had engineers examine and sample the gold lode property of B1ll Lyons and C. if. Bradley on Bird Creek in the Telkeetna diatrlot. The property has long been considered by experts to bo quite promising. Richardson plans large-scale exploratory work and development if the results of the preliminary work are satisfactory to his finencial beckers. News reports atate that he has staked considerable ground adjacent to the property.

B111 zyons, President of Seldotla Mining and Treding Conpany, plans to put the old Chrome Queen property at Red Mountain into produotion as soon as conditions perintt.

Mining has commenced for the season at the Kenal Chrome Company property at Red Mountain. They hope to be shlpping chromite by early August. A tram will not be built ag planned earlier, but the ore will be brought down off the mountain by crewler tractor and trafler. 
FOURTH DIVISION - Fred hesemen, $1546 \mathrm{~s}$ : Cushman Street, Fairbenks, who handles various types of radiation detecting equipment, has aet up an aerial radiation teating unit on the roof of his establyshent, the first of its kind in the Territory. It is for the purpose of testing and calibrating air-borne Geiger counters, sointillometers, and nucleometers. The output or the unit is such that airoraft $\because *$ with counters can easily detect the radiation at an altitude of 1,000 fert. The radiating unit $1 \mathrm{~s}$ made by The Radium Company of America and is fully tested and approved. The bullding below $1 \mathrm{t}$ is prótected from possible damage by a lead shleld.

\section{OLI NEWS}

The Alaske 011 and Gas Development Company has struck promising Ges Indieations at depths of 1,200 feet and lower at their driling alte neav Eureka on the Glem Highway.

Drliling in the Goose Bay area, across Knik Arn from Anchorage, 1s being planned by the Alaska Gulf 011 and Gas Development Corporation. They intend to bring a large rotary drill $\mathrm{r} \pm \mathrm{g}$ and experienoed drillere from californta for the venture.

The Hevenstrite dr1lling operation at Chinitna Bay should get under way by late July. A road is beine built to the drilling site, a canp is being erected. and over 1,000 tons of aupplies have been unloaded at the beacl. A dock was improvised by sinking a barge and filling $1 \mathrm{t}$ with rocks.

Bomer and vicintty $1 \mathrm{~s}$ the scene of extensivg selamic exploration for ofl indications. Standerd oll is believed to be financine, this work, while Shell ofi is reported to heve flelo parties working on the opposite side of cook Inlet from Homer. The selsmlc work is being carried out at a rapid $r$ ate with truck-mounted drills drilling the shot holes, and a total orew of about 20 men.

Kerr-McGee has fintshed their first test well near Yakataga with negative results, and 1s now preparing to start on the second hole. A total of about 12 wella are to be drilled in the area, according to their contract with the people holding the leaseg on the ground.

\section{NEV PUBLICATIONS}

The Canadian Gological Survey hes written and published a very practical booklet entitled Prospecting for Uranium in Canada, which will be found to be of 1nterest and help to Alaskan miners and prospectors. Chapters in the booklet, whlch can be atudied or used to an advantage in Alaska, are as follows: "General Information Necessary for the Prospector," "Devices und Methods ior Detecting Rad "gctivity," "Testa for Uranium $\mathbb{R}$ lement," "Use of Geiger counters and Sointilletion Instruments in Prospecting," and "Sampling and Evaluation of Uranium D1scoveries." This booklet can be obtained from the Territorial Department of Mines offlces until our small supply is gone, or from the cueen's Printer at ottawa, The pries is fifty centa.

The AEC booklet, Prospecting With a Counter, whlch was announced in our Warch Bulletin and wich was out of print before Alaskans had time to purchase them, is expected to be avalleble again in the near future. 


\section{OURRENI METAL PRICES}

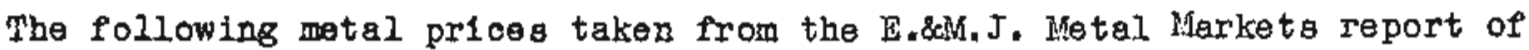
July 1, 1954, should be of interest to the prospector and miner:

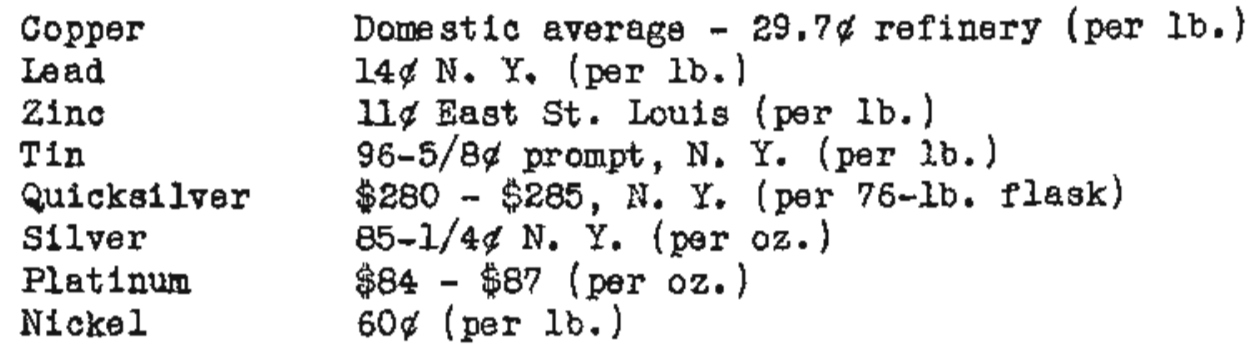

\section{NEWS FROM THE AMERICAN MTNING CONGRESS BULLETINS}

TEXAS TIN SMELTER: $\mathrm{s}$. Con. Res, 79, introduced by 3enate Minority Laader Johnson (Dem.,Tex.) (BuIl: \#11, p.5), has been pessed by the Senate and sent to the House,

The resolution expresses the "sense of Congress" that the Government ahould continue to operate the Texas clty tin smelter until June 30,1955 , and provides for a atudy group under the Senate Armed Services and Sente Benking Coinittees to look 1nto the "desirability of a permanent domestic tin-swelting industry."

Pessage of the resolution was prompted by the tense situation existing in southeast Asia and by strong representations by Alaskan tin producers against the Government's sbutting down of the smelter. The Fouse Armed Services comittee is expected to give prompt approval to the resolution and House approval at an arrly dete is $1 \mathrm{~kg}$ ly. It $1 \mathrm{~s}$ bellered that President Llsenhower will endorse the legislat1on and order the gmelter's reopening.

The Administration had previously indicated that the operation of the smelter, the only major plant of 1 ts kind in the Western Hemisphere, would be terminated at the end of this month.

MLNE CLATM ASSESSMENT: Rep. EAgle (Dem. "Colif.,) has warned mining clatm owners that they mugt complete work on the1r annual assessments for this year by July 1 .

Engle stated that nany claimholders are under the impresa1on that $\mathrm{S}$. 2320, introduoed by Senator Mhrray (Dem., Mont.), whloh passed the Senete last year and would extend the date for completing the assessment work to October 1 , has beome law.

The measure is atill in the House Rules Comittee, and Fngle said thest it Is likely that $1 t$ will not be passed by the Bouse before the JuIy 1 deadine, and pos: bly will not be acted on st this session.

\section{NEVS FROR EQMT METAL \& MITERAL MALKITS}

President Eisenhower last week directed the Secretary of the Treasury to orgentze the Federal Fecllitieg Corporation to take over the responsibility of oporating the Texaa City tin amelter after the Reconstruction Finance corporation goes out of business on June 30 . 